\title{
Order on Their Home Fronts: Imagining War and Social Control in 1950s NATO
}

\author{
Iben Bjørnsson
}

'Keep Calm and Carry On'. The iconic UK wartime poster is one of many examples of governments instructing people how to behave in war or crisis. From Duck and Cover cartoons, to farmers' handbooks, civil populations grew used to seeing such instructions in the twentieth century. In this chapter, I ask what ideas they built on. What were the origins and expressions of those ideas, their traces in modern history and their development with (thermo)nuclear weapons?

The subject of analysis is the NATO Civil Defence Committee and the Senior Committee for Civil Emergency Planning. Being fora for exchange and (some degree of) coordination between Western countries, these committees are obvious but understudied sources when dealing with civil defence cultures and attitudes. They will be analysed in a broader framework of Western scientific culture, total war and, not least, the theoretical framework of the sociotechnical imaginary.

I. Bjørnsson ( $\square)$

Stevnsfort Cold War Museum, Roedvig, Denmark e-mail: ib@oesm.dk 
The time frame is the 1950s, which established the thermonuclear age. It is also NATO's first decade of existence in which it negotiated its role in the new world order.

The article falls in four sections. First, I introduce the theoretical framework of the study, as well as the historical background: the modern Western cultural tradition of dealing with human fear in times of crises. Following this I investigate how war and civil populations were imagined in NATO in the 1950s and, in the next section, how this was underpinned by science. Lastly, I ask what NATO thought could or should be done. In the conclusion, I will tie the analysis to the theoretical framework, to say something about the larger picture of what preparedness meant to NATO and Western society.

\section{SOCIOTECHNICAL IMAgINARIES AND CONCEPTS OF WAR}

The notion of the sociotechnical imaginary rests on the idiom of coproduction, which holds that development is powered by intertwined processes of technology and science informing culture and politics, and vice versa. Sociotechnical imaginaries are such negotiations of science into power structures. Hence, they are normative: they express (un)desired orders and strive to have a governing and/or disciplining function; they too are instructions in behaviour (Jasanoff 2004: ch. 1-2; Jasanoff 2015: 2-4).

The definition at first glance seems to favour the positive, 'desirable futures'. But Jasanoff notes that a desirable outcome correlates with an obverse scenario: 'shared fears of harm' and 'negative imaginings'—utopia vs. dystopia (Jasanoff 2015: 4-5). She does actually extend the definition, albeit in a parenthesis, beyond 'collectively held and performed visions of desirable futures' to 'resistance against the undesirable' (Jasanoff 2015: 19). With this subtle addition, a sociotechnical imaginary can also be a safeguard against an undesired future or dystopia. As we shall see, this is the case in this chapter.

Imaginaries are constituted by '[p]erformances of statehood [...] tied to demonstrations and to public proofs employing scientific and technological instruments' (Jasanoff 2015: 9-11). Most obvious is the scientific test, but such performances can also take the form of moon landings, complicated surgery - or civil defence exercises: calm, rational behaviour acted out as both rehearsal and theatre, aimed to ensure 'calm and 
composed [...] subjects' (Ziauddin 2017: 9; Cronqvist 2008; Davis 2007).

In this chapter, I will operationalise the framework of sociotechnical imaginaries to look at how science underpinned social order(s) and what this can tell us about what was (un)desirable. For this purpose, it is important to note that the sciences employed might not only be technological, but also human and social.

One of the most common human reactions to war or catastrophe (and indeed danger at large) is fear. But while fear is among the most basic of instincts, historian Joanna Bourke shows how fear as a societal phenomenon changed character in the nineteenth and twentieth centuries. Scientific developments created new things to fear, and rising secularisation of Western societies shifted responsibility for handling societal fears from the church to secular authorities (Bourke 2006: 23-24). These authorities sought help from the burgeoning psychological and social sciences around the turn of the century. Hence, these sciences came to serve as a tool not only for better understanding the human mind, but also for defining desirable states of mind and treating undesirable ones. They were employed by authorities to make sense of modernity, but also advanced by modernity itself.

One manifestation of fear is panic. And a phenomenon of urban living is so-called mass panic. That this could be deadly became clear in the late nineteenth and early twentieth centuries when it broke out in enclosed areas, like theatres and on factory floors. Thus, panic was now something to be handled by authorities, and the regulation of public space for the purpose of (emotional) management of people became a marker of modernity (Bourke 2006: 5lff). Panic also became an area of research for the psychological sciences. In the late nineteenth century, theories of 'the group mind' identified panic as a contagious phenomenon, causing otherwise sensible and rule-abiding individuals to behave irresponsibly and immorally. Panic was the opposite of civilisation and sociability, efficiency and progress. The volatile crowd, uncontrolled, could wreak political, social and economic havoc. Sociologists spoke of disorganised and selfish behaviour as an expression of instinct normally covered in the veneer of civilisation, but susceptible to activation by fear (Bourke 2006: 6lff). Human fear, if not handled, could be a steppingstone towards chaos.

With the great wars of the twentieth century, the insights from these scientific delvings into human fear were put into practice on soldiers. A finding from the First World War was that fear could be calmed 
by, or channelled into, activity. The worst thing for the mental wellbeing of a soldier was being unable to do anything - the best was to be prepared and trained. Fear took nourishment from rumours and insecurity and could be relieved by the presence of calm and confident authority figures (Bourke 2006: 208ff; Davis 2007: 115). These observations were confirmed during the Second World War, in which the view also evolved that fear was not something one should strive to eradicate or be free of, but rather a natural and even healthy reaction to a critical situation which could spur further action (Biess 2009: 219-220; Bourke 2006: 212; Oakes 1994: 50, 62-64).

These studies, which initially looked at soldiers, were replicated in civilian life. In 1939, the British War Office conducted investigations into avoiding civil panic, the results of which were in line with what had already been established: fear and panic could be relieved by proper preparation, information control and a sense of responsibility. The ability to do something was essential, and this should be trained beforehand, as recognisability and repetition promoted a sense of security. If this did not work, however, there were other, hands-on methods: British civil defence personnel were trained in 1940 to 'treat' panic-stricken persons with a bucket of water or a punch in the nose or ear. Panic was contagious and had to be shut down immediately (Bourke 2006: 224, 244ff).

Studies of civilian populations' actions and their role in a war was a result of the totalisation of war, another feature of the twentieth century. This indicates that war was no longer just a military matter, but also a civil one. Total war was facilitated by technological advances, especially in air force technology, which led wars far into territories beyond the front. It was also helped along by radio and (moving) images bringing faraway battlefields into theatres and living rooms. Hence, governments sought to mobilise the home front, where maintaining the morale of civil populations was essential. Civilians were rallied to participate in the war effort through a steady stream of messages: grow vegetables, 'keep mum', buy war bonds. Keep calm, carry on. Civil defence is in itself an expression of the totalisation of war, which civil society was now asked to confront and tackle (McEnaney 2000; see also Hogg, this volume, Fig. 2.1).

In Cold War USA, civil panic was deemed so decisive for a war that it could even be used deliberately. The US Joint Chiefs of Staff believed the 'chaos and extreme confusion', 'hopelessness and shock' and 'aimless, even hysterical activity' following a nuclear attack on the enemy could work effectively to their own advantage (Oakes 1994: 33, 35-36). 


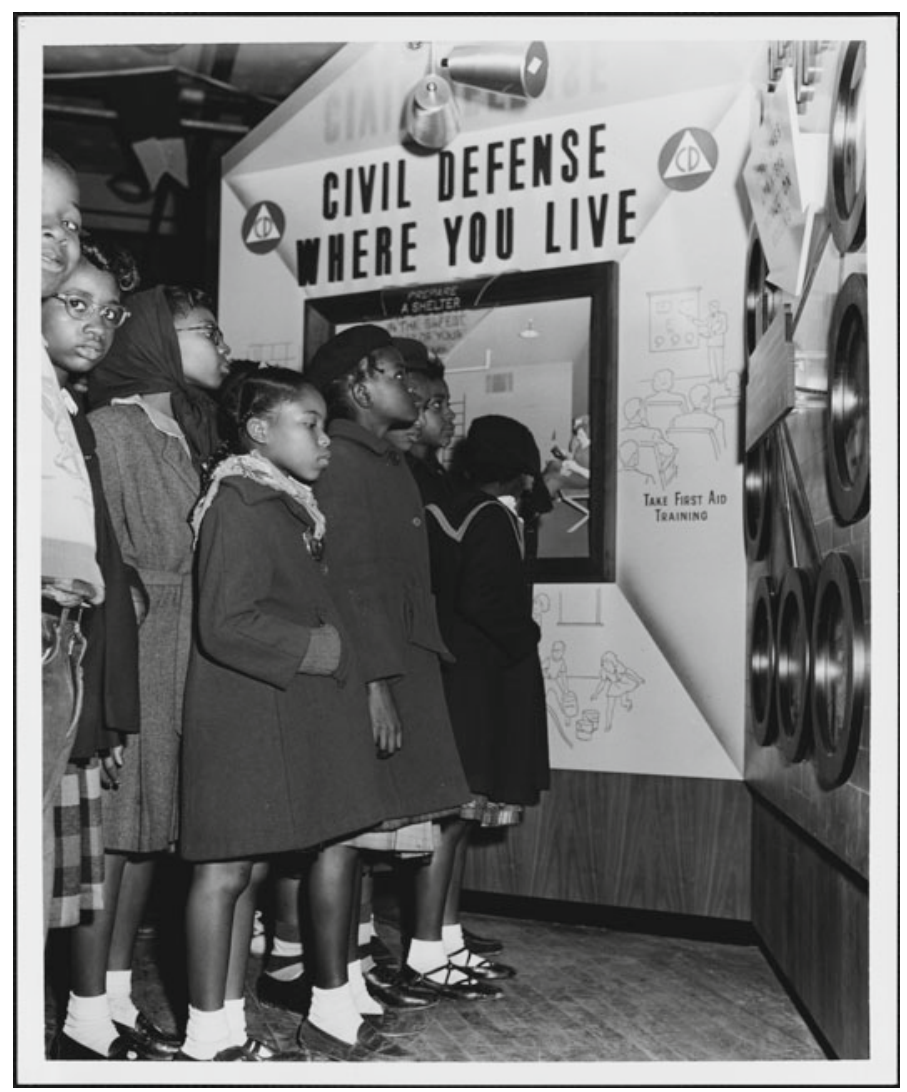

Fig. 2.1 The mobile civil defence exhibition 'Alert America' travelled the USA in 1952-55

It was one of many attempts to mobilise the 'home front' and make preparedness for war a feature of civil society (Photo: US National Archives, https://www.dig italcommonwealth.org/search/commonwealth:h128rr89n)

In 1951, the US Federal Civil Defense Administration (FCDA) and the Pentagon launched a civil defence research project, Project East River, that repeated earlier conclusions: panic could lead to disobedience and even resistance, protests, vandalism and riots. The road from panic to civil unrest to uprisings seemed all too short, and panic was viewed as a subversive, perhaps even revolutionary, phenomenon. But project East River also 
found remedy in the established methods: preparation and having something to do combined with establishment of authority and information control (Oakes 1994: 40-42, 62ff; Grossman 2001: 59-61; Bourke 2006: 270ff; McEnaney 2000: 31-33; Davis 2007: 120).

Project East River's results became authoritative within American civil defence. It stood on the shoulders of existing war and disaster research, both American and European, and the results and recommendations were fundamentally the same. As such, East River both drew from existing research trends and fed back into them.

With Project East River in mind, it is perhaps not strange that the USA took a keen and early interest in panic prevention. President Eisenhower believed that, in war, both civilians and officials would lose their minds, and he was generally pessimistic about being able to do anything about it. According to Val Peterson, US Federal Civil Defense Director from 1953 to 1957 , 'mass panic may be far more devastating than the bomb itself'. ' One FCDA official estimated that the larger part of their work in the 1950s was about panic prevention (Oakes 1994: 41-42, 150-151; Davis 2007: 122; Bourke 2006: 268-269).

Another expression of the interest in (unwanted) mental reactions to disaster, which began in military medicine and worked its way into civil defence circles in the 1950s, was the development of psychological first aid as a field - the skill of soothing a shocked mind (Blain et al. 1945; Drayer et al. 1954).

We see here the contours of a sociotechnical imaginary in which panic and disorderly, individualised behaviour was undesirable. Its precise origins are hard to pinpoint, but modernity, urban masses and modern warfare were all elements in its creation. Formulated positively, this imaginary envisioned calmness in catastrophe fostered by proper training and education and adherence to authority: a civil defence culture of preparedness and deference (Cronqvist 2012). However, it was mostly formulated negatively, in terms of what would happen if preparedness failed: as an undesirable.

According to Lord Ismay, NATO General Secretary from 1952 to 1957, when he took office, he asked Supreme Allied Commander in Europe (SACEUR) General (later US President) Eisenhower how he, Ismay, could best be of service. Eisenhower answered that he needed Ismay to keep up morale on the home fronts. ${ }^{2}$ In a memorandum to the North Atlantic Council shortly thereafter, Ismay wrote that modern war was no longer just a military effort, but 'a trial of strength and willpower 
between whole nations or groups of nations', and without a stable home front, the military effort would be futile. ${ }^{3}$ The NATO Civil Defence Committee (CDC) were formed around the same time, in the summer of 1952. Civil defence was a direct result of the totality of modern war.

\section{Imagining War and Civil Defence in i95os NATO}

When imagining war, people usually go by experience. This was also the case in postwar Europe (Grant 2016: 96). However, the Cold War contained a threat with which very few people had experience, namely nuclear weapons. The only people who had actually experienced their impact were in Japan. But while images were available to European audiences, this did not fundamentally alter the European vision of war: a bombed-out city looks the same whether its name is Hiroshima or Hamburg (Ziemann 2016: 117-118; Molitor and Hogg, this volume). Thus, Hiroshima and Nagasaki were woven into the existing European visions of war without fundamentally altering them.

Not having a recent memory of war on their own territory, Americans had to go 'on imagination alone' (Oakes 1994: 5). According to UK planners, this caused American authorities to focus more on panic, whereas British authorities considered their population already well trained in handling war (Grant 2010: 11). Or perhaps the Americans just took seriously their own research from Hiroshima and Nagasaki, which stated that:

... the primary reaction to the bomb was fear - uncontrolled terror, strengthened by the sheer horror of the destruction and suffering witnessed and experienced by the survivors. (...)

The two typical impulses were those: aimless, even hysterical activity, or flight from the city to shelter and food.

An interviewee was quoted: 'I became hysterical (...) and we just ran around without knowing what to do'. 4

Apart from these differences, both US and Western European authorities and (civil) defence planners initially thought a Third World War would be survivable. A war was not thought to be wholly nuclear, and the atomic bomb was mostly considered a very large, but otherwise normal bomb. Civil defence could build directly on the Second World War experience and did not have to undergo fundamental change. Oakes considers 
this 'conventionalisation' of the A bomb a stunt to reassure the population (Oakes 1994: 5lff), but the general impression from at least Danish and NATO sources is that civil defence authorities sincerely believed this. Whether that was just a case of them being duped by the Americans is not to be speculated on here. But it should be added that all discussions about nuclear weapons in the CDC were informed by Hiroshima/Nagasaki and nuclear tests made by the USA. As such, the American interpretation held sway. ${ }^{5}$

At a CDC meeting in late 1953, the American delegation showed the nuclear test film Operation Doorstep. It showed the effect of the A bomb on such things as wooden houses, subterranean shelters and cars. The blast was 15 kilotonnes (kt.) - Hiroshima-sized —and the comforting message was that less than a mile from the explosion itself (ground zero) humans could survive if properly prepared and sheltered. What it did not say, but which the American delegate disclosed at the meeting, was that $15 \mathrm{kt}$ was already considered relatively small and that this bomb had been detonated at an altitude which minimised its effect. A larger bomb detonated higher in the air would have been 'much more devastating'. 6

In May 1955, the FCDA invited the entire CDC to visit the Nevada desert themselves and observe another test, Operation Cue. This test was also framed reassuringly: although the reinforced wooden house 5,500 feet from the explosion lost roof, chimney and windows, the mannequins serving as the family in the basement were unharmed. The model power plant and communication lines also survived. Once again, the conclusion was that with proper preparation, an atomic explosion could be both managed and survived. ${ }^{7}$ Footage of these tests were broadcast to the American public and are a prime example of the publicly performed scientific test which sought to attest to and solidify the civil defence imaginary (Fig. 2.2). ${ }^{8}$

However, in the early- to mid-1950s a new type of nuclear weapon emerged: the hydrogen $(\mathrm{H})$ bomb. The strength of the $\mathrm{H}$ bomb is not counted in kilo- but in megatonnes (a thousand times more powerful), which made it increasingly impossible to pretend-or believethat nuclear weapons could be likened to conventional bombs. The $\mathrm{H}$ bomb was accompanied by a shift in US and NATO strategic doctrines; the 1953 New Look strategy of the Eisenhower administration was based primarily on nuclear weapons and was followed by the NATO doctrine of massive retaliation-all-out nuclear response to an attack. Not only did nuclear weapons become more terrifying, but a future war became 


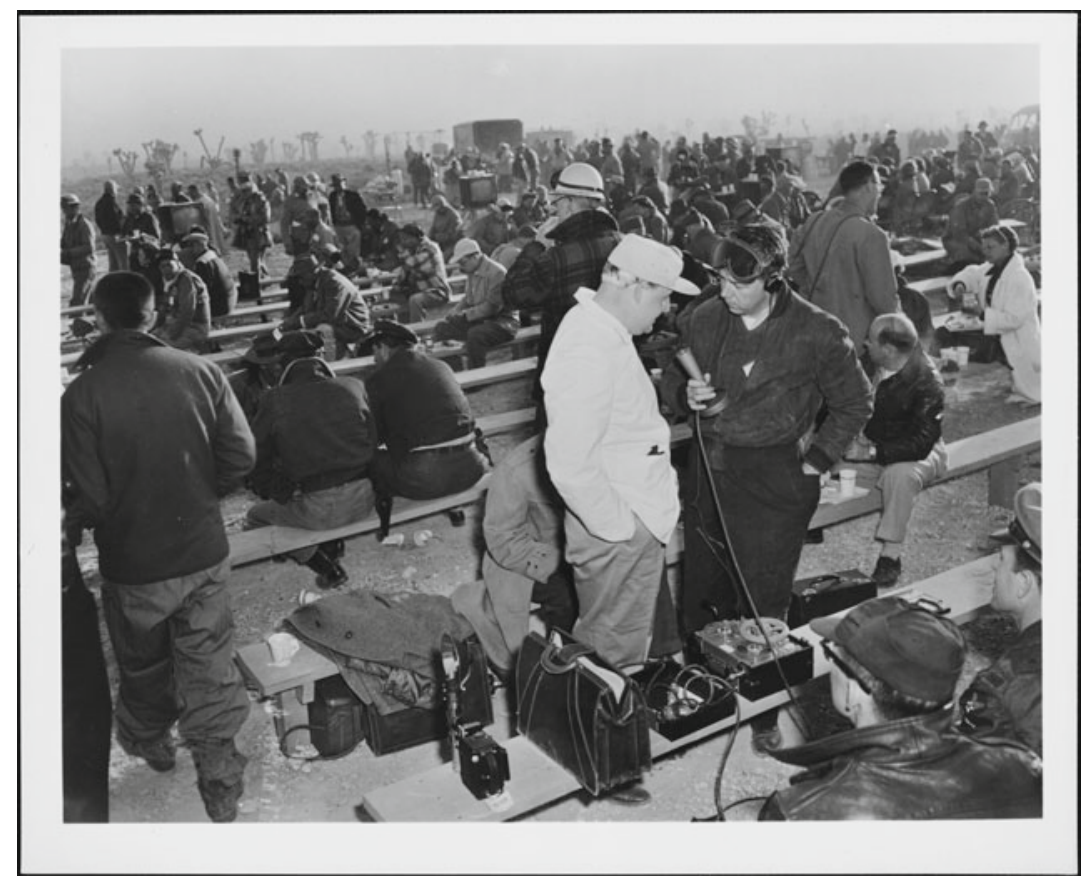

Fig. 2.2 The nuclear test as a public performance and media event FCDA Director Val Petersen is interviewed at the observer area of the Operation Cue atomic blast in 1955 (Photo: US National Archives, https://www.digitalco mmonwealth.org/search/commonwealth:h128s189g)

almost wholly nuclearised (McMahon 2010: 293). As these developments made war equally unpredictable and indeed unimaginable on both sides of the Atlantic, experience no longer counted (Rose 2001: 38; Grant 2016: 101ff, 132; Horn 2016: 33-34, 47). British authorities started doubting that their otherwise experienced population would 'keep calm and carry on' in thermonuclear war. Panic ceased to be mainly an American concern (Grant 2010: 50, 112; Hennessy 2010: 153-154, 177).

Initially, the FCDA did try to maintain an image of the $\mathrm{H}$ bomb as merely a VERY big, but otherwise still normal, bomb (Oakes 1994: 5862). This was evident at a May 1954 CDC meeting where FCDA Deputy Director Katherine Howard stated that its destructive effects were greatly exaggerated by the media. Though more powerful, it was not essentially 
different from the A bomb, so nothing would fundamentally have to change. She concluded that 'precautions could be taken against the effects of this weapon' and showed 'no sign of pessimism on this point'.?

This time, however, the rest of the committee was not convinced. During 1954, the Danish Civil Defence Directorate's scientists began questioning assumptions about protection against the $\mathrm{H}$ bomb. ${ }^{10}$ This reached Director Arthur Dahl during his tour of the USA in autumn 1954, where he saw for himself that American civil defence plannerscontrary to Howard's statements-were adjusting to thermonuclear reality by transitioning from a strategy of shelters to evacuation. ${ }^{11}$ Upon return, he brought it up in the CDC, stating that many of the known protective measures were already outdated and that civil defence also needed a 'New Look'. British representative General F. Irving agreed. He stated directly that they had to stop talking about what had worked in the last war and start talking about what to do in a future one. The UK, he said, had no intention of spending more money on measures that did not also protect against thermonuclear weapons. Val Peterson admitted that the best defence against the $\mathrm{H}$ bomb was dispersal of people and vital installations, and he confirmed that the USA had started making extensive evacuation plans. CDC chairman Laborie asked for a revision of current work, and NATO Civil Defence Advisor John Hodsoll promised to do a review. ${ }^{12} \mathrm{He}$ was not the only one: centrally, NATO had also started work on new planning assumptions, which Hodsoll drew upon in preparing his report.

Hodsoll's report (ready in just a week) stated that the $\mathrm{H}$ bomb fundamentally altered things and that the 'general arrangement' of the last war was no longer sufficient. Where the goal then had been to uphold everyday life and production albeit at a reduced level, everything now had to be about immediate survival. 'Business as usual' did not exist when everything within a radius of seven miles from ground zero was devastated. Now, 'everything would have to be temporarily subordinated to the maintenance of life and health; in other words, to the basic essentials of human existence'. Invoking the language of total war, Hodsoll stated that measures would be 'aimed at preserving the civil population and sustaining their morale, since if they collapse their country will cease to be a combat unit' and concluded: 'The Home Front is fundamental. If it collapses all is lost'. ${ }^{13}$

The new NATO planning assumptions, which had informed Hodsoll's memorandum, were adopted by the North Atlantic Council in May 1955. 
They heralded a new era, foreseeing that 'on the outbreak of hostilities, the enemy will launch thermo-nuclear attacks with first priority' and that 'thermo-nuclear weapons can create destruction and chaos on a scale exceeding anything hitherto contemplated'. ${ }^{14}$ It was thought that an initial intense nuclear bombing period of three to seven days would be followed by a 30-day period which determined whether or not a nation survived. In this light, the Council encouraged NATO members to prioritise planning for survival in the first 30 days of war. Survival was defined as 'maintenance of the authority of the government and the preservation of human life'. 15

These changes led to a reorganisation in which all NATO committees on civil planning, including the CDC, were put under a new Senior Committee for Civil Emergency Planning, for the purpose of securing cohesive and focused planning. This included but also went beyond civil defence: civil emergency planning encompassed all civil and societal measures directed at securing the survival of the nation in accordance with the Council's definition, including safe locations for governments, emergency laws, communication lines, infrastructure and shipping. ${ }^{16}$

\section{BRINGING IN SCIENCE}

The preoccupation with panic and upholding authority spread across the Atlantic and took a hold in NATO circles, even its top tier: in 1955, Deputy Supreme Allied Commander of Europe (DSACEUR) Field Marshall Montgomery stated that one of nuclear war's big dangerswhich might even end up costing victory-was 'hysteria'. ${ }^{17}$

It also became the subject of interest for civil defence and preparedness sciences which, up to that point, had mainly dealt in more quantifiable topics such as thickness of bunker walls, blast effects and radiation levels. A sociotechnical imaginary is underpinned by, and intertwined with, science. Therefore, the emergence of psychology in scientific debates in civil defence circles also tells us something about how the imaginary developed. The increased focus on psychological sciences in NATO/Western European civil defence circles in the 1950s informs us of a sociotechnical imaginary that increasingly explicated its visions of behaviour.

By comparing and contrasting four articles by medical professionals on the subject in the time span of 1956-1958, we shall see that, although the thermonuclear era was new, the particular problem of panic and unrest, as well as its cure, were closely in line with previous thinking. 
The articles are 'Views on psychological reactions in war' ('Synspunkter på psykiske reaktioner under krig') by Swedish Civil Defence Surgeon General Dr Walo von Greyerz, 'Maintenance of morale among civilians during a nuclear emergency' by Chairman of NATO's Medical Committee Dr Svend Toftemark of the Danish Ministry of Health, 'Civil morale under the threat of nuclear attack' by psychiatrist at the Department of Psychological Medicine at London University College Hospital Dr Roger Tredgold and 'Psychological considerations in Civil Defence Planning' by British professor of psychology Thomas Ferguson Rodger. All four articles struck the following themes in more or less detail: desired and undesired symptoms of fear and remedies in the form of preparation, information, activity, authority and-in some cases-force.

Some were very particular about describing symptoms. Von Greyerz divided fearful reactions into two categories, each containing three subcategories with symptoms ranked from mild to severe. The first category contained uneasiness, apprehension and anxiety. Uneasiness was a normal reaction to war, but via apprehension it could escalate to anxiety, which demanded treatment. Whereas the first category was permanent or longer-lasting problems, the symptoms in the second category-fear, dread and terror-were more immediate reactions. Otherwise the principle was the same-a normal reaction could escalate into an unhealthy one:

During an air raid, we share fear with everyone around us, and we don't have to be ashamed of it. We must receive it as something natural. But if fear - via the intermediate stage, which I call dread - increases to terror, it will have reached proportions where it can no longer be accepted as an ally. ${ }^{18}$

If fear was allowed to escalate into terror there were two possible outcomes: apathy, where people would lose all ability to act and the storm', where they would run around bewildered, incapable of reasonable action, perhaps even displaying symptoms such as blindness, deafness, numbness or unconsciousness (a state which he labelled 'hysteria'). If a 'terror psychosis' 'infected' the surroundings, it could 'drive a whole group to actions that go against common sense; this is when panic arises'. ${ }^{19}$

Tredgold ranked reactions to fear more simply: as either 'healthy' or 'unhealthy'. Unhealthy reactions were 'panic, paralysis, overactivity, 
bodily complaints (based largely on anxiety) and depression which may lead to fatalistic (and fatal) resignation'. Fear in itself, however, was natural and only 'exaggerated' reactions to it were unhealthy. ${ }^{20}$ Much the same was expressed by Toftemark and Ferguson Rodger. The latter, however, ranked panic as more detrimental than apathy. He stated that a 'dazed apathetic state' was a relatively normal reaction to catastrophe, and preferable to 'excited behaviour'. ${ }^{21}$

There were different views as to what panic looked like. To Tredgold, panic (or 'overactivity') might on the surface look purposeful, but on inspection it was more like a fish on dry land, 'floundering about to no purpose, gasping and with an occasional convulsive jerk'. ${ }^{22}$ Ferguson Rodger took almost the opposite approach: purposeful behaviour could look like panic for the uninitiated, who only saw 'what appears to be random, uncontrolled activity' with people 'running or driving vehicles in opposite directions, often at times passing each other without acknowledgment or seeming awareness'. This, however, was 'not panic, but social disorganization. Many individuals and small groups are working within the disaster area with purpose and some degree of organization'. Nor was flight necessarily panicked; in fact, 'it is more often orderly and controlled', but could also, to the uninitiated look disorganisedwhich was why journalists often exaggerated and over-reported panic. He reminded the reader that panic had actually been rare during the last war. ${ }^{23}$ This point was also made by von Greyerz, who reassured the reader that panic had 'only in exceptional cases been a serious problem'. He also made the point that what could look like panic at first glance, like mass flight, could in actuality be rational and 'have an objective in sight'. ${ }^{24}$

As such, they differed on how reactions should be categorised and on the nature of events of panic. But they all thought it best to prevent them altogether, and largely agreed on the means: 'The three big musts of panic prevention are preparation, information and action'-these were the words of Toftemark, although he was himself rather pessimistic as to how well it would work. He thought that even prior education of people could not ensure that they would react correctly in an emergency. Its effectiveness required them to be both psychologically and emotionally involved, which in turn required authorities to counter indifference not only with information, but also with positive motivation and a realistic picture of the options. ${ }^{25}$ Von Greyerz also expressed the view that peacetime preparation and education was of the utmost importance-including the knowledge that fear was natural and could be remedied. ${ }^{26}$ Tredgold 
made the same point, noting that what a threat meant to the individual 'will depend largely on what he has been told about it'. ${ }^{27}$

Ferguson Rodger thought that a prepared population would react adaptively and that the civil population could be trusted with the initiative in an emergency-the most important thing was that they be properly informed both ahead of but also during a catastrophe. ${ }^{28}$ So everyone agreed that preparation was key, even if Toftemark was somewhat pessimistic about people's involvement in the prior preparation. This problem was, however, a known one. Civil defence authorities hit this wall time and again trying to 'educate' a public which seemed indifferent to or even ridiculed the attempts. However, the stance of the authorities was clear: it was better to repeat the message and hope something stuck than to have an utterly oblivious population (Davis 2007: 170).

Everyone also agreed that information to the population once disaster had struck was as crucial as information beforehand. Information could itself relieve fear: for instance, noise from anti-aircraft weapons would be perceived as less unnerving if people knew that it was a welcome part of their own defence. As von Greyerz stated: 'People who know what has happened are considerably better equipped to bear the burden of reality, than those who are in the dark'. ${ }^{29}$ Ferguson Rodger recommended giving people 'clear and unambiguous information, even if it is of the gravest import'. If people were 'as well informed as possible', then they would stay rational and make the right choices. Lack of information, on the other hand, was a source of panic. ${ }^{30}$ This also implied that even bad news was better than none. The unknown was always scarier than reality. According to Tredgold, there was a real chance of 'panic caused by gross over-imagination. I can understand that there may be reluctance to tell people horrible facts, but they will indulge in more horrible fears if they are not told'. ${ }^{31}$

This information, obviously, should come from people in authority, and this was another common feature of the articles. Von Greyerz stated that fear in a person could be relieved alone by someone else's 'firm demeanour', ${ }^{32}$ and Toftemark emphasised the necessity of constructive and authoritative role models to prevent the spread of uncontrolled and individualised behaviour. While some initial 'disorganization' could not be avoided, the trick was to quickly establish organisation and action by strong leadership. ${ }^{33}$ Ferguson Rodger's biggest worry was people isolated in fallout shelters for too long. This was not only bad for mental health in general but could also lead to the very lack of information which incited 
fear-and panic. Therefore, fallout shelters should be regularly patrolled by authorities with tidings. ${ }^{34}$

Authorities could also give people something to do, and this was another most relished remedy of fear with all authors. Fear and action were intertwined: fear could spur action and action remedied fear. Activity of any kind was good-according to von Greyerz, 'preferably a simple task which is physically strenuous, like handing water or carrying bricks' ${ }^{35} \mathrm{It}$ could not only hinder fear from turning into panic, but also, according to Dr Threadgold, even remedy paralysis and 'bodily complaints'. ${ }^{36}$

Lastly, the authors mentioned those instances where the sufferer was not able to act on their own or under instruction because they had entered a state of panic. Both Toftemark and Tredgold mentioned the relatively new term 'psychological first aid' as a remedy that should be trained in advance. Tredgold recommended that people be led away from the disaster and calmed down before further action could be taken. Calming down could mean anything from a cup of tea to sedation, and the article focused on treating people with empathy, praising them when they did something sensible or worthwhile. If people turned to religion, this should be encouraged (whatever one's own personal attitude), as it could soothe mental suffering. Through these remedies, the doctor thought morale could be raised considerably, and mental damage prevented from being long-term. Von Greyerz also recommended sedation as treatment for both apathy and terror. Furthermore, he recommended removing the sufferer from others so as it would not 'rub off'. If this was not a possibility, for instance in a shelter, a last resort could be to tie down and gag the afflicted person, although not without taking care to explain to others present why such extreme measures were necessary. ${ }^{37}$

Apart from differences in nuances and categorisation, it is striking how similar these articles are, in both their diagnoses and recommended remedies. It is fair to say that Western civil defence psychology was a research field marked by consensus, and it is also worth noting that it correlates with earlier military psychology. Although it was a new field of research, it was rooted in a firm tradition (as was civil defence and disaster medicine as a whole, see Molitor, this volume). This sociotechnical imaginary that favoured calmness and preparedness had been extended from military medicine to civil defence science and thus reinforced. 


\section{Control}

Mass panic is tied to a loss of control: the individual losing control over themselves and authorities losing control over populations. With maintaining government authority as a top priority, control of the population also quickly became a main priority for the Senior Committee, and it delegated the issue to the CDC. Val Peterson agreed and even stated in a Civil Defence meeting that control of the population was the most important aspect of any defence, civil or military. 'In his own country they were still very dubious regarding public reaction in the event of a war'.38 The message was also employed at top level. Leaving office in 1957, NATO General Secretary Lord Ismay stated that it was the 'bounden duty of every Government to do its utmost' to ensure that in a war, 'the civil population and civilian activities would be efficiently controlled and directed'. 39

Hence, control of the population was one of the first things the Senior Committee asked the CDC to review. Hodsoll responded with a September 1956 memorandum in which he earnestly stated that it was not something they had hitherto considered or even defined. In his definition, control meant having the population '(a) maintain their morale; (b) do what they are told, (c) do everything possible to help themselves'. The reasoning behind putting morale before obedience was that Hodsoll thought it was a prerequisite for exercising 'reasonable control' over people. Once people lost their spirit, it 'might easily result in the population degenerating into an unorganized and undisciplined mob, with all the consequences which that would imply'. While admittedly not previously having dealt with the issue, Hodsoll had quickly learned the language of this particular imaginary and its dystopia of the uncontrolled mob.

To sustain morale - and thereby control-Hodsoll, in line with the existing research consensus, considered it 'of cardinal importance' that the population be prepared and educated in peacetime. This was, incidentally, also all that NATO could do. Procedures for 'actual control'-execution of orders and regulations-were a matter for the individual countries' executive powers. ${ }^{40}$ But as these functions may also be halted during a war, Hodsoll underlined that 'control, to be successful, must rely in the main on the self-discipline of the population, their ready acceptance of whatever orders are issued and their co-operation in such a way as to make such orders succeed'. Ideally, control was not to be enforced 
by already strained authorities but exercised from within subjects themselves. Self-help was 'a relief for the trained forces', but-also in line with existing research-he recommended some presence of authority to keep up morale and control. Martial law might be necessary in 'very adverse circumstances', but he recommended it only as 'a last resort'. ${ }^{41}$

Throughout 1957, several member countries submitted memoranda to the CDC on the issue. With slight variations, their focus was roughly the same: peacetime education and training and wartime establishment of authority and communication. ${ }^{42}$ In an attempt to further structure these efforts, Hodsoll, in a January 1958 memorandum, divided measures into three situations: peacetime, a period of tension and war. Education and preparation should be done in peacetime, as surprise by the nature of nuclear war 'might rapidly [...] lead to panic and disorder'. If there were a period of pre-war tension, governments should issue preparatory instructions. In war, communications should be established as quickly as possible, especially to spread the message that 'the Government is still in control and knows what it is doing'. This should be backed by visible action and presence by local authorities or civil defence forces. ${ }^{43}$ The sudden and overwhelming focus on control in the CDC made the Turkish representative remark at a 1957 meeting that some extent of population protection was presumably still needed-otherwise there would be no one left to control (Fig. 2.3). ${ }^{44}$

In 1958, NATO's Military Committee adopted a document known as MC70, which re-evaluated the alliance's force requirements and strategy. The document mentioned enemy psychological operations against morale and suggested the necessity of forces 'for maintaining order behind the combat zone', without going into further detail. ${ }^{45}$ MC70 was an elaboration of MCl4/2 of May 1957, which stated as a 'Defence Principle' under the North Atlantic Treaty, that

[i]t is a responsibility of national authorities to develop plans and measures which will ensure the continuity of governmental control following a sudden outbreak of hostilities and will also ensure the maintenance of civilian morale coupled with the ability to prosecute the war to a successful conclusion. ${ }^{46}$

The North Atlantic Treaty itself, however, does not mention morale or continuity of government. One previous strategic document, MC48/1 of 


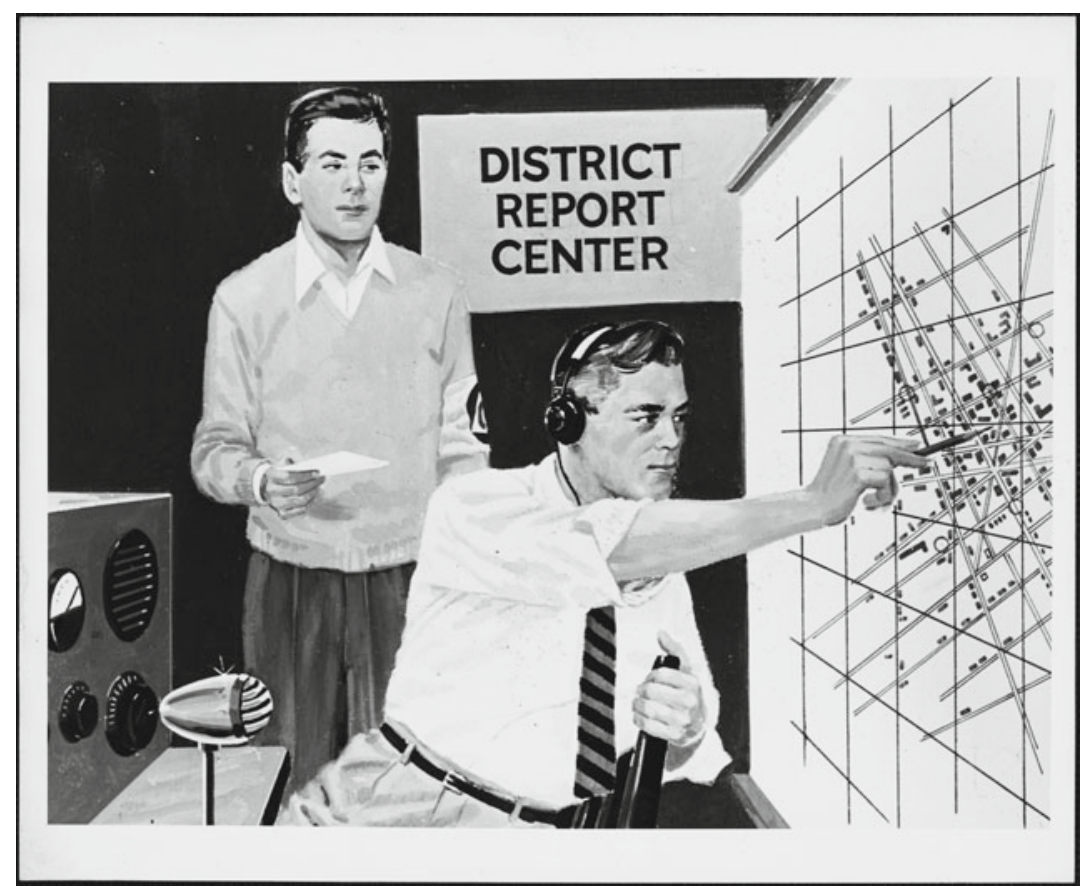

Fig. 2.3 A vision of a government that is in control and knows what it is doing

In the 'Alert America' exhibition, people were assured that civil defence personnel would have a cool overview, guide citizens to proper locations and inform them what to do (https://www.digitalcommonwealth.org/search/commonwealth:hl2 $8 \mathrm{rn} 65 \mathrm{f}$ )

December 1955 mentioned it in more lofty terms. Thus, the thermonuclear era had worked the issue of morale and control into official NATO strategy documents. This fact was taken as further confirmation by the CDC that an increased focus on 'prevention of panic' was warranted and that 'nations must be prepared to maintain order on their Home Fronts'. 47

But once again, studying and making recommendations was all the CDC was able to do. ${ }^{48}$ While the Senior Committee encouraged these studies it also recognised that the issue itself lay beyond the scope of 'purely civil defence $[\ldots]$, since it entered into the maintenance of public order and consequently was related to the maintenance of government 
control'. ${ }^{49}$ As was once again established, actual maintenance of law and order was a job for the national governments. ${ }^{50}$ The Senior Committee would, however, in the following years continue to urge nations to prioritise planning for maintenance of government control, including emergency laws and preparation.

Although not equipped with authority to execute it, the CDC continued studying and discussing related issues such as wartime command, control and communications, assistance of armed forces to civil defence, and the role of central and local government employees in war. As such, the element of (controlling) human reactions had made its way into emergency planning with the thermonuclear era.

\section{CONCLUSION}

When authorities imagined war, it wasn't always with the greatest of confidence in their populations. Authorities feared that citizens' fear would express itself in panic, which was considered dangerous and destructive. The need to tackle and control the base instincts of the population was older than, but intensified by, the advent of nuclear and thermonuclear weapons. In the early 1950s, fear of panic thrived especially with American civil defence planners, but the $\mathrm{H}$ bomb spread it to Europe. While it might not be possible to pinpoint an exact origin, we see a consistency of Western cultural thought dating back to the establishment of the modern psychological and social sciences. The civil defence dystopia of the uncontrollable mob was culturally consistent with earlier images, as was the belief (or hope) that this was somehow manageable by science. The nuclear and thermonuclear ages were thus negotiated into pre-existing frameworks of both civil defence and desired social order and were informed by research preceding it.

While the nuclear apocalyptic was (re-)negotiated into these lines of thought, the advent of the $\mathrm{H}$ bomb added a new sense of urgency. Prior to the establishment of the Senior Committee, the CDC and articles in the Civil Defence Bulletin had often enough underlined the importance of morale, but never entertained scenarios of chaos and human liability to the extent that it was done in the mid to late 1950s. Morale, having previously mainly been about spirit and support, was now directly tied to control. From not having been articulated at all, control of populations was now catapulted into top priority-especially as civil emergency planning emerged with its focus on maintaining government authority. In 
this particular nuclear dystopia, losing the lives of the population would be bad. Losing control over them would be even worse.

Imaginaries are mostly group achievements (Jasanoff 2015: 25). So was this one: it was formulated, shared and distributed by a civil defence community not only informed by, but equipped with, its own scientists, media and advisors. With nations employing their own scientists and experts, as most national civil defence directorates did, this also secured the continued co-production of this imaginary. In this case it also received the backing of the mighty NATO, which not only worked to extend the sociotechnical imaginary back to national governments, but also served as a forum for spreading and solidifying it.

But there were limitations. NATO's Civil Defence and Senior Civil Emergency Committees never faced up to a full panic scenario. While experts talked about physical measures like sedating or even fixating people, official documents consulted for this article only hinted at physical measures such as riot control or martial law. This was not solely due to unwillingness to discuss an unpleasant topic, but also due to the fact that execution of such powers was a national affair. NATO could negotiate, streamline and seek to extend the imaginary, but its final embedding was up to national governments. Some embraced it, pouring millions into both material and non-material preparations, ${ }^{51}$ whereas most renegotiated it into a local setting. And while the imaginary might be collectively held by authorities, how it fared in civil society, and the resistance it met, is another, no less interesting, question (which is explored in several chapters in this volume).

Viewing the culture of Cold War preparedness promoted by civil defence organisations as a sociotechnical imaginary makes sensealthough in this case, one must insist that science is not only technological or material. Science is also humanities, social, political and psychological, and those were the primary sciences at work here. This particular sociotechnical imaginary was also not formulated as a utopia, but a dystopia-nuclear war and, with it, a total collapse of society and the humans in it. Any desirable images in here were those of well-behaved, adaptable and docile citizens, a best-case scenario within the worst.

But this does not only tell us something about how war was imagined. Sociotechnical imaginaries are often a function of existing power/social order and aimed at preserving it (Jasanoff 2015: 21, 25-26). And what the fear of populations tells us about Cold War Western society might be the most tangible lesson. Civil defence, as other research has pointed out, 
was as much about reassuring people and securing their support for the security politics $d u$ jour as it was about, as this chapter has shown abundantly, upholding the control of existing orders. If the docile, calm and obedient behaviour desired in war was extended 'backwards' into peacetime, both governments and planners were better off. The Cold War was also total, and the home front needed mobilisation in peacetime as well. Civil defence did not just serve the purpose of assuring the public that they would be able to 'do something'-it was also about making them do the 'something' which they were told to do.

Thus, civil defence and preparedness were not only narratives of a future war, but also a narrative of the desirable citizen at large. The fixation on upholding government control as the most important prerequisite for a nation's survival and the almost nightmarish visions of panic, chaos and destruction say a lot about another dystopia, one in which Western populations would no longer support the Cold War ideological order. Making people feel like they would be okay, it was hoped, would make them less likely to revolt, and that was a central tenet of civil defence as well as society in general. As such, the sociotechnical imaginary of preparedness culture had the purpose of supporting and enforcing existing power relations.

The imaginary had a function not only in war, but also in peace. Education and preparation were one side of a coin that had social control as the other.

\section{Notes}

1. Collier's Weekly, 21 August 1953, 99-109. https://www.unz. com/print/Colliers-1953aug21-00099/ [accessed 16 October 2020].

2. AC/23-R/5: Record of Civil Defence Committee meeting 9-10 February 1953. NATO Archives 01-The North Atlantic Council, AC/23 Series, 1953, Records.

3. C-M(52)27: Civil organization in North Atlantic Treaty countries in times of war. 5 June 1952. NATO Archives, 01, C Series, 1952, Memoranda.

4. U.S. Strategic Bombing Survey: The Effects of the Atomic Bombings of Hiroshima and Nagasaki. 19 June 1946. Truman Library, 
https://www.trumanlibrary.gov/library/research-files/united-sta tes-strategic-bombing-survey-effects-atomic-bombs-hiroshima-and [accessed 16 October 2020].

5. AC/23(CD)-D/44: Report summarizing all answers, 28 May 1953.

6. Operation Doorstep, Periscope Film. https://archive.org/det ails/28072OperationDoorstep [accessed 16 October 2020]. AC/23(CD)-R/3: Record of meeting. 11 November 1953.

7. AC/23(CD)D/108: Experimental atomic explosion in Nevada. 10 June 1955, Operation Cue (1955). https://www.youtube.com/ watch?v=zU91CKDzKSY [accessed 16 October 2020].

8. Wills (2019). On the role of civil defence films in constructing imaginaries, see the chapters by Hogg and Bennesved and Sylvest, this volume. On the normalisation of nuclear weapons, see also Hogg.

9. AC/23(CD)R/4. Record of meeting. 17 May 1954.

10. Brev fra Schultz til Dahl, 5 October 1954. Rigarkivet (Danish National Archives) 1261: Beredskabsstyrelsen, Civilforsvarsdirektør E. Schultz' embedsarkiv, 63: Breve 1950-61, læg 1.

11. 'Nogle hovedindtryk af amerikansk civilforsvar', 10 January 1955. Schultz, Materiale vedr. udlandet 1947-1983, 217: USA 1951$1960 \mathrm{~mm}$., USA 1951-1955.

12. AC/23(CD)R/5: Record of meeting, 15-16 November 1954.

13. AC/23(CD)D/98: Civil Defence and Thermo-Nuclear Weapons, 25 November 1954; Orientering 3, 19 March 1956. Schultz, Mødereferater, diverse udvalg 1947-1983, 195.

14. C-M(55)48(Final): The application of the new assumptions to the work of the emergency planning committees. 27 May 1955.

15. C-M(55)48(Final): The application of the new assumptions to the work of the emergency planning committees. 27 May 1955.

16. AC/23(CD)D/112: Application of the new planning assumptions to the work of the Civil Defence Committee, 3 August 1955; C-M(55)75: US proposal for reorganization of civil emergency planning, 20 August 1955; C-R(55)37: Council meeting 14 September 1955; AC/23(CD)D/110: Revised draft report in current work in the light of the new assumptions. 19 September 1955; C-M(55)95: Draft resolution, 3 November 1955 and C-M(55)100: Final resolution, 10 November 1955; C-R(55)50: Record of council meeting. 14 November 1955. 
For earlier drafts and discussion of these, see AC 95 Series. $\mathrm{AC} / 23(\mathrm{CD}) \mathrm{D} / 124$ : Application of the new planning assumptions to the work of the Civil Defence Committee. 19 December 1955; AC/23(CD)D/124(Final). Application of the new planning assumptions to the work of the Civil Defence Committee, 19 April 1956; AC/23(CD)R/7: Record of meeting. 2 December 1955.

17. 'Field Marshal Montgomery warns on "great danger of hysteria" after attack', NATO Civil Defense Bulletin August 1955. Schultz, NATO-CF-Bulletiner 1947-1983, 201: 1954-1959.

18. Synspunkter på psykiske reaktioner under krig, Orientering 8, 24 September 1956. Schultz, Mødereferater, diverse udvalg 19471983, 195. Title and quotes translated from Danish by the author.

19. 'Synspunkter på psykiske reaktioner under krig', Orientering 8, 24 September 1956. Schultz, Mødereferater, diverse udvalg 1947$1983,195$.

20. 'Civil morale under the threat of nuclear attack', NATO Civil Defence Bulletin March 1958. Schultz, NATO-CF-Bulletiner 1947-1983, 201: 1954-1959.

21. 'Psychological considerations in Civil Defence Planning', NATO Civil Defence Bulletin March 1959. Schultz, NATO-CF-Bulletiner 1947-1983, 201: 1954-1959.

22. 'Civil morale under the threat of nuclear attack', NATO Civil Defence Bulletin March 1958. Schultz, NATO-CF-Bulletiner 1947-1983, 201: 1954-1959.

23. 'Psychological considerations in Civil Defence Planning', NATO Civil Defence Bulletin March 1959. Schultz, NATO-CF-Bulletiner 1947-1983, 201: 1954-1959.

24. 'Synspunkter på psykiske reaktioner under krig', Orientering 8, 24 September 1956. Schultz, Mødereferater, diverse udvalg 1947$1983,195$.

25. 'Maintenance of morale among civilians during a nuclear emergency', NATO Civil Defence Bulletin October 1957. Schultz, NATO-CF-Bulletiner 1947-1983, 201: 1954-1959.

26. 'Synspunkter på psykiske reaktioner under krig', Orientering 8, 24 September 1956. Schultz, Mødereferater, diverse udvalg 19471983, 195.

27. 'Civil morale under the threat of nuclear attack', NATO Civil Defence Bulletin March 1958. Schultz, NATO-CF-Bulletiner 1947-1983, 201: 1954-1959. 
28. 'Psychological considerations in Civil Defence Planning', NATO Civil Defence Bulletin March 1959. Schultz, NATO-CF-Bulletiner 1947-1983, 201: 1954-1959.

29. 'Synspunkter på psykiske reaktioner under krig', Orientering 8, 24 September 1956. Schultz, Mødereferater, diverse udvalg 19471983, 195.

30. 'Psychological considerations in Civil Defence Planning', op. cit. Underlinings in original text.

31. 'Civil morale under the threat of nuclear attack', NATO Civil Defence Bulletin March 1958. Schultz, NATO-CF-Bulletiner 1947-1983, 201: 1954-1959. This was reflected by increasing 'realism' in at least Danish and Swedish civil defence films from the late 1950s, see Bennesved and Sylvest, this volume.

32. 'Synspunkter på psykiske reaktioner under krig', Orientering 8, 24 September 1956. Schultz, Mødereferater, diverse udvalg 1947$1983,195$.

33. 'Maintenance of morale among civilians during a nuclear emergency', NATO Civil Defence Bulletin October 1957. Schultz, NATO-CF-Bulletiner 1947-1983, 201: 1954-1959.

34. 'Psychological considerations in Civil Defence Planning', NATO Civil Defence Bulletin March 1959. Schultz', NATO-CFBulletiner 1947-1983, 201: 1954-1959.

35. 'Synspunkter på psykiske reaktioner under krig', Orientering 8, 24 September 1956. Schultz, Mødereferater, diverse udvalg 19471983, 195.

36. 'Civil morale under the threat of nuclear attack', NATO Civil Defence Bulletin March 1958. Schultz, NATO-CF-Bulletiner 1947-1983, 201: 1954-1959.

37. 'Synspunkter på psykiske reaktioner under krig', Orientering 8, 24 September 1956. Schultz, Mødereferater, diverse udvalg 1947$1983,195$.

38. AC/23(CD)R/10: Record of meeting, 12-13 March 1957.

39. NATO. April 1952 - April 1957. Text of Lord Ismay's Report to the Ministerial Meeting of the North Atlantic Council in Bonn, May 1957. NA 04, Public Diplomacy Division, NATO Publications, NATO Non-Periodical, 1957.

40. AC/23(CD)D/151: Control of civilian population under attack. 6 September 1956. 
41. AC/23(CD)D/151: Control of civilian population under attack. 6 September 1956.

42. 1957: AC/23(CD)D/192 (Netherlands), AC/23(CD)D/195 (UK), $\mathrm{AC} / 23(\mathrm{CD}) \mathrm{D} / 200$ (Belgium), $\mathrm{AC} / 23(\mathrm{CD}) \mathrm{D} / 202$ (Turkey) and AC/23(CD)D/204 (Luxembourg). 1958: $\mathrm{AC} / 23(\mathrm{CD}) \mathrm{D} / 244$ (Germany).

43. AC/23(CD)D/216: Control of the Population, 21 January 1958. 44. AC/23(CD)R/11: Record of meeting, 19-20 November 1957.

45. MC70: The Minimum Essential Force Requirements, 1958-1963. 29 January 1958. NA 03, MC Series, 1958.

46. MC14/2 (Revised) (Final Decision). Overall Strategic Concept for the Defense of the North Atlantic Treaty Organization Area. 23 May 1957.

47. AC/23(CD)D/297: Civil Emergency Planning AssumptionsThe Effect of the New Military Appreciation. 16 October 1958.

48. AC/23(CD)D/293: Suggestions by the United Kingdom delegation on heading under which the Civil Defence aspects of 'Control of the population' might be studied by NATO. 12 February 1959; AC/23(CD)D/193: Fallout control demonstration by the United Kingdom delegation. $2^{\text {nd }}$ September 1957; AC/98-R/4: Record of meeting, 15-16 October, 30 October 1957.

49. AC/23(CD)N/40: Control of the population. October 1958. AC/23(CD)R/13: Record of meeting 25-26 November 1959.

50. AC/23(CD)D/283: Control of civilian population. 21 November 1958.

51. See especially Bjørnsson (2020), Frandsen (2020), Rimmen Noe et al. (2017), Aagard (2018) and the chapters by Farbøl and Bennesved and Sylvest, this volume.

\section{REFERENCES}

\section{UNPublished SOURCES}

RA: Rigsarkivet (Danish National Archives).

1261: Beredskabsstyrelsen, Civilforsvarsdirektør E Schultz' embedsarkiv.

Breve 1950-1982, 63: Breve 1950-1961.

Mødereferater, diverse udvalg 1947-1983, 195. 
Materiale vedr. udlandet 1947-1983, 217: USA 1951-1960 mm. USA 1951-1955.

NATO-CF-Bulletiner 1947-1983, 201: 1954-1959.

\section{Online Sources}

NA: NATO Archives-www.archives.nato.int

01: The North Atlantic Council

$\mathrm{AC} / 23$ : Committee on Civil Organization in Time of War

AC/23(CD): Civil Protection Committee

AC/95: Working Group to Examine the United States Proposal for

Reorganization of the Civil Emergency Planning Structure

AC/98: Senior Civil Emergency Planning Committee

C-North Atlantic Council

03: Military Committee

MC-Military Committee

04: International Staff / International Secretariat Public Diplomacy Division, NATO Publications

Colliers Weekly archive-https://www.unz.com/print/Colliers/

Truman Library

United States Strategic Bombing Survey: 'The Effects of the Atomic Bombs on Hiroshima and Nagasaki', June 30, 1946-https://www.tru manlibrary.gov/library/research-files/united-states-strategic-bombing-sur vey-effects-atomic-bombs-hiroshima-and? documentid=NA\&pagenumber $=1$

Operation Doorstep-https://archive.org/details/28072OperationDoorstep Operation Cue (1955)—https://www.youtube.com/watch?v=zU91CKDzKSY

\section{LITERATURE}

Aagaard Jensen, Sanne. 2018. Nuclear-proof communications? The Cold War and the governance of telecommunications security in NATO and Denmark. PhD Thesis, University of Copenhagen.

Biess, Frank. 2009. 'Everybody has a chance': Nuclear angst, civil defence, and the history of emotions in Postwar West Germany. German History 27: 215243.

Bjørnsson, Iben. 2020. 'Stands tilløb til panik'. Civilforsvarspjecer som social kontrol. In Atomangst og civilt beredskab, eds. Marianne Rostgaard and Morten Pedersen, 65-102. Aalborg: Aalborg Universitetsforlag.

Blain, Daniel, Paul Hoch, and V. G. Ryan. 1945. A course in psychological first aid and prevention. American Journal of Psychiatry 101: 629-634. 
Bourke, Joanna. 2006. Fear: A cultural history. London: Virago.

Cronqvist, Marie. 2008. Utrymning i folkhemmet: Kalla kriget, välfärden och den svenska civilförsvarskulturen 1961. Svensk Historisk Tidskrift 128: 451-476.

Cronqvist, Marie. 2012. Survival in the welfare cocoon: The culture of civil defence in Cold War Sweden. In Cold War cultures: Perspectives on eastern and western European societies, eds. Anette Vowinckel, Marcus M. Payk and Thomas Lindenberger, 191-210. New York: Berghahn Books.

Davis, Tracy C. 2007. Stages of emergency: Cold War nuclear civil defense. Durham: Duke University Press.

Drayer, Calvin S., Dale C. Cameron, Walter D. Woodward, and Albert J. Glass. 1954. Psychological first aid in community disaster. Journal of the American Medical Association 156: 36-41.

Frandsen, Bodil. 2020. Det centrale civile beredskab og REGAN Vest. In Atomangst og civilt beredskab, eds. Marianne Rostgaard and Morten Pedersen, 27-63. Aalborg: Aalborg Universitetsforlag.

Grant, Matthew. 2010. After the bomb: Civil defence and nuclear war in Britain, 1945-68. Houndmills: Palgrave Macmillan.

Grant, Matthew. 2016. The imaginative landscape of nuclear war in Britain 1945-65. In Understanding the imaginary war: Culture, thought and nuclear conflict, 1945-90, eds. Matthew Grant and Benjamin Ziemann, 92-115. Manchester: Manchester University Press.

Grant, Matthew, and Benjamin Ziemann, eds. 2016. Understanding the imaginary war: Culture, thought and nuclear conflict, 1945-90. Manchester: Manchester University Press.

Grossman, Andrew D. 2001. Neither dead nor red: Civil defense and American political development during the early Cold War. New York: Routledge.

Hennessy, Peter. 2010. The secret state: Preparing for the worst 1945-2010, second edn. London: Penguin Books.

Horn, Eva. 2016. The apocalyptic fiction: shaping the future in the Cold War. In Understanding the imaginary war: Culture, thought and nuclear conflict, 1945-90, eds. Matthew Grant and Benjamin Ziemann, 30-50.

Jasanoff, Sheila. 2004. The idiom of co-production. In States of knowledge: The co-production of science and social order, ed. Sheila Jasanoff, 1-13. London: Routledge.

Jasanoff, Sheila. 2015. Future imperfect: Science, technology and the imaginations of modernity. In Dreamscapes of modernity, eds. Sheila Jasanoff and Sang-Huyn Kim, 1-33. Chicago: Chicago University Press.

McEnaney, Laura. 2000. Civil defense begins at home: Militarization meets everyday life in the fifties. Princeton: Princeton University Press.

McMahon, Robert J. 2010. US national security from Eisenhower to Kennedy. In The Cambridge history of the Cold War. Volume I: Origins, eds. Melvin P. Leffler and Odd Arne Westad, 288-311. Cambridge: Cambridge University Press. 
Nowak, Lars. 2016. Images of nuclear war in US government films from the Early Cold War. In Understanding the imaginary war: Culture, thought and nuclear conflict, 1945-90, eds. Matthew Grant and Benjamin Ziemann, 26086. Manchester: Manchester University Press.

Oakes, Guy. 1994. The imaginary war: Civil defence and American Cold War culture. Oxford: Oxford University Press.

Rimmen Noe, Bjarke, Andreas Lie Stokbro, and Andreas Juel Høj. 2017. Tryghed på tryk: Det danske presseberedskab under den kolde krig. Master's Thesis, Aalborg University.

Rose, Kenneth D. 2001. One nation underground: The fallout shelter in American culture. New York: New York University Press.

Rostgaard, Marianne, and Morten Pedersen, eds. 2020. Atomangst og civilt beredskab: Forestillinger om atomkrig i Danmark 1945-1975. Aalborg: Aalborg Universitetsforlag.

Wills, John. 2019. Exploding the 1950s consumer dream: Mannequins and mushroom clouds at Doom town, Nevada test site. Pacific Historical Review 88: 410-438.

Ziauddin, Silvia Berger. 2017. (De)territorializing the home: The nuclear bomb shelter as a malleable site of passage. Environment and Planning D: Society and Space 35: 674-693.

Ziemann, Benjamin. 2016. German angst? Debating Cold War anxieties in West Germany, 1945-90. In Understanding the imaginary war: Culture, thought and nuclear conflict, 1945-90, eds. Matthew Grant and Benjamin Ziemann, 116-139. Manchester: Manchester University Press.

Open Access This chapter is licensed under the terms of the Creative Commons Attribution 4.0 International License (http://creativecommons.org/licenses/ by $/ 4.0 /)$, which permits use, sharing, adaptation, distribution and reproduction in any medium or format, as long as you give appropriate credit to the original author(s) and the source, provide a link to the Creative Commons license and indicate if changes were made.

The images or other third party material in this chapter are included in the chapter's Creative Commons license, unless indicated otherwise in a credit line to the material. If material is not included in the chapter's Creative Commons license and your intended use is not permitted by statutory regulation or exceeds the permitted use, you will need to obtain permission directly from the copyright holder.

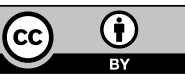

